\section{Sensitivity of human bone marrow cells to cyclosporin $\mathbf{A}$}

FROM observations of the effect of cyclosporin A in vitro on committed progenitor cells of the myeloid and erythroid series (CFU-C and BFU-E), Gordon and Singer ${ }^{1}$ have inferred that cyclosporin A has non-myelotoxic immunosuppressive activity. We find this a disturbing conclusion because although similar studies in this laboratory ${ }^{2}$ using the semisolid agar CFU-C assay ${ }^{3}$ showed almost identical dose-related inhibition of CFU$\mathrm{C}$, our results also suggested that sensitivity to cyclosporin $\mathrm{A}$ is related to the level of differentiation of progenitors in the granulocyte-monocyte pathway, the more primitive progenitors being more sensitive. This is important because the pluripotent haematopoietic stem cell (CFU-S) from which CFU-C are derived and on which haematopoietic recovery in marrow transplantation depends, may be more sensitive to cyclosporin $A$ than results of CFU-C assays indicate.

There is now considerable evidence that clone size potential decreases and sensitivity to factors with colony-stimulating activity (CSA) increases as progenitor cells differentiate down the granulocytemonocyte pathway ${ }^{4,5}$.

Our experiments showed that: (1) cells forming small clones were less sensitive to cyclosporin A than cells forming large clones; (2) cells requiring the highest levels of CSA for clone formation (that is, the most primitive progenitors) were more sensitive than cells forming clones at lower CSA levels.

\section{Correlation between heart attacks and magnetic activity-a retraction}

WE recently showed a significant correlation between the daily sums of $\mathrm{Kp}$, the planetary index of geomagnetic activity, and the daily admissions of cardiac emergency cases to the two main hospitals in Hyderabad and Secunderabad ${ }^{1}$. Richard Peto of the Radcliffe Infirmary, Oxford, has re-examined our data, and finds that their distribution about the regression line is grossly sub-poissonian. This means that the correlation is higher than would be expected even if magnetic activity were the sole cause of heart attacks, and casts serious doubt on the authenticity of the data. The magnetic activity data are those published by the International Association of Geomagnetism and Aeronomy, and are above suspicion. The medical data are those used by Srivastava, Bhaskara Rao and Saxena ${ }^{2}$ and were abstracted by colleagues of Srivastava (Bhaskara Rao, Saxena and two others) from individual case sheets and the hospital records. Srivastava and Saxena have re-examined
Both observations point to a trend of increasing sensitivity to cyclosporin $\mathrm{A}$ as the CFU-C/CFU-S transition is approached and thus to the possibility of considerable myelotoxicity in conditions where CFU-S are rapidly proliferating. Even without speculating on the sensitivity of CFU-S, our results for CFU-C detected at the highest CSA levels (approximately 50,70 and 90\% inhibition at 1,5 and $10 \mu \mathrm{g} \mathrm{ml}^{-1}$ of cyclosporin A, respectively) are disturbing, as 5$10 \mu \mathrm{g} \mathrm{ml}^{-1}$ was required for near-maximal inhibition of the most sensitive $T$ lymphocyte colony-forming cell population in two of three patients studied by Gordon and Singer ${ }^{1}$.

\section{G. E. FRANCIS}

J. J. BERNEY

\section{Department of Haematology,}

The Royal Free Hospital,

Hampstead, London NW3, UK

1. Gordon, M. Y. \& Singer, J. W. Nature 279, 433-434 (1979).

2. Francis, G. E. et al. Scand. J. Haemat. (submitted).

3. Pike, B. L. \& Robinson, W. A. J. cell. Physiol. 76, 77-83 (1970).

4. Francis, G. E. et al. Br. J. Haemat. 41, 545-562 (1979).

5. Francis, G. E. Med. Hypoth. 5, 999-1006 (1979).

GORDON AND SINGER REPLY-The point that cyclosporin A may be considered to have some myelotoxicity in vitro is well taken. In terms of bone marrow engraftment, however, myelotoxicity has not been a problem. Cyclosporin A increases the survival of rabbits grafted

the hospital records, which are now in a more accessible form, and are unable to reproduce the numbers abstracted earlier. We conclude that the medical data used in the two studies ${ }^{1,2}$ are spurious, and any results derived from them should be disregarded. This may explain why Knox et al. have carried out a similar enquiry and failed to confirm our claims ${ }^{3}$.

We are grateful to Dr Peto for drawing our attention to this matter, and apologise for publishing a misleading result.

\section{S. R. C. MALIN}

Institute of Geological Sciences,

Murchison House,

West Mains Road, Edinburgh, UK

\section{B. J. SRIVASTAVA}

National Geophysical Research Institute, Uppal Road, Hyderabad 500 007, India

1. Malin, S. R. C. \& Stivastava, B. J. Nature 277, 646 (1979), 2. Srivastava, B. J., Bhaskara Rao, D. S. \& Saxena, S. Ind. J. Radio Space Phys. 5, 114 (1976).

3. Knox, E. G., Armstrong, E., Lancashire, R., Wall, M. \& Haynes, R. Nature 281, 564-565 (1979) with allogeneic marrow ${ }^{1}$ and is an effective prophylaxis against graft-versushost disease in $\operatorname{man}^{2,3}$.

Francis and Berney have suggested that pluripotential stem cells (CFU-S) may be more sensitive to the compound than committed progenitor cells (CFU-G) and that cyclosporin A may have greater toxicity towards rapidly proliferating cells. These suggestions are based on the findings that small clones, grown in agar culture, are less sensitive to cyclosporin A than large clones and that sensitivity to the compound increases with the amount of colony-stimulating activity

presented to the treated cells.

(CSA)

Our data ${ }^{4}$ do not show whether cycling and non-cycling haematopoietic progenitor cells differ in their sensitivities to cyclosporin $\mathrm{A}$ as the study used normal steady-state cells. This aspect is certainly of interest and experimental evidence can be obtained by studying the effects of cyclosporin A on patients' colony-forming cells following bone marrow transplantation.

The design of the experiments ${ }^{5}$ said to show an effect of CSA activity on cell sensitivity to cyclosporin $\mathrm{A}$ involves a preincubation step before the cells are washed and plated in agar. It seems reasonable to suggest that the apparent effect of CSA activity on cell sensitivity may result from an altered responsiveness of the cyclosporin A-treated cells to CSA (or to inhibitors). Again, this can be tested by producing full dose-response curves of post-cyclosporin A cells, preferably to a cell-free source of CSA, which will give more reliable results than cellular feeder layers.

\section{Y. GORDON}

Department of Haematology,

Royal Postgraduate Medical School, Hammersmith Hospital, London, UK

\section{J. W. SINGER}

Veterans Administration Hospital, Seattle, Washington

1. Jacobs, P. et al. Int. Soc. Haemat. II (abstr.) 17 (1979)

2. Powles, R. L. et al. Lancet II, 1327 (1978).

3. Powles, R. L. et al. Int. Soc. Haemat III (abstr.) 87 (1979).

4. Gordon, M. Y. \& Singer, J. W. Nature 279, 433-434 (1979).

5. Francis, G. E. et al. Scand. J. Haemat. (submitted).

\section{Glaciation due to continental drift}

COGLEY ${ }^{1}$ has suggested that a special distribution of land is needed during glacial periods. He proposes that the onset of glaciation occurs when land masses congregate in the tropics. The average global temperature decreases as the polar regions become "slightly warmer while 